\title{
脳卒中片麻痺による足部変形に対する手術療法
}

水俣市立湯之児病院リハビリテーションセンター
山 本 正 昭・浅 山
森
山 本 敬 三・高 橋

\section{The Surgical Treatment of Equinovarus and Claw Toe Deformities in Adult Hemiplegia}

\author{
by
}

\author{
M. Yamamoto, K. Asayama, K. Morimoto, S. Takahashi, \\ H. Yamanaga and M. Tsukano \\ from Yunoko-Byoin Rehabilitation Center, \\ Minamata Municipal Hospital
}

\begin{abstract}
The commonest deformities seen in hemiplegic foot are equinovarus and claw toe which often respond to simple operative procedures. However, repeated preoperative assesment as an inpatient is essential because paralysis of central nervous system is different from peripheral nerve injury. From 1973 to 1979 ninety-one patients have undergone operation at our Center. The operation carried out, either singly or in combination, Vulpius's procedure, transfer of tibialis anterior, release of long toe flexors and elongation of the tibialis posterior. Correction once achieved is stable and the deformity does not recur. These operation benefited the patients in so far as more can walk afterwards, there is less deformity and there is less spasticity.
\end{abstract}

\section{はじめに}

片麻㽻における機能再建の歴史は，きわめて浅く， 欧米においても 1961 年の Treanor の報告が最初で あり, 本邦においては1967 年, 小野, 三島, 田川ら の報告以来のことである.片麻㾝による足部変形は直 接歩行障害に関与するだけに，その機能再建の意義は 大きい.

われわれは, 1973 年以来, 約 100 例の片麻㾝によ る足部変形に対し，実用歩行獲得の目的で手術療法を 行い, 良好な結果を得ているので, われわれの手術の 適応及び方針について簡単に述べてみたいと思う.

手術の目的は，あくまでも実用歩行の獲得であり， そのためには, 変形の矯正と拘縮の除去, 二次的な変 形・拘縮の防止，治療期間の短縮及び装具の着用を容 易にするなどの目的があげられる，しかし，片麻㾝患 者では, 高齢者が多く, また内科的にも種々の合併症
をあつことが多いため，侵襲の少ない麻醉で，かつ長 期間の臥床やギプスによる固定を必要としないような 手術が適当と思われる.

\section{症例及び方法}

症例は 91 例で, 年令は 18 才より 82 才, 男 60 例, 女 31 例, 右片麻㾝 40 例, 左片麻㾝 51 例であった. 行った手術は, 腓腹笳腱切離いわゆるVulpius 法 77 例, 長母趾屈笳腱切離 79 例, 長趾屈筋腱切離 77 例, 前脛骨筋腱移行 37 例, 後脛骨筇腱延長 2 例, 短 趾屈 筋腱切離 1 例であり，それぞれの手術を症例に応じ組 合せて行った（図 1).

手術適応に関する因子としては, 高度の内科的合併 症, 精神障害, 障害受容の欠如, 意欲の欠如, 持続性 弛緩麻㾝, 高度の知覚障害及び疼痛, 麻㾝側下肢の回 復度, 健側下肢の支持力などを考慮しなければならな い. 
われわれは, 脳卒中罹患後, 一応プラトーに達した と思われる患者で, 手術により安定した歩行が得られ ると思われるものを手術の適応としている.

さて, 片麻㾝患者の足部に最む多く見られる変形 は, 内反尖足及び槌趾である. しかし, 中枢神経麻疩 による変形は，末梢神経麻㾝のそれとは本質的に異な り，てれら変形に関与する筋群とその程度を把握する ことは，手術法選択のため重要であるが必ずしあ容易 な事ではない。

内反尖足に関しては，一般に痤直性麻㾝において は, 抗重力筋である腓腹筋の関与が大きいといわれて いる. 下腿三頭筋を弛緩させる方法は, 種々試みられ ているが，われわれは侵襲が少なく，かつ翌日より歩

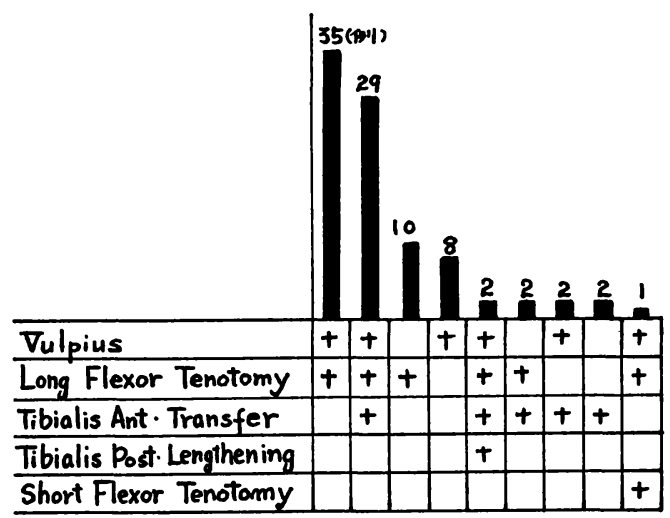

図1手術の組合せ

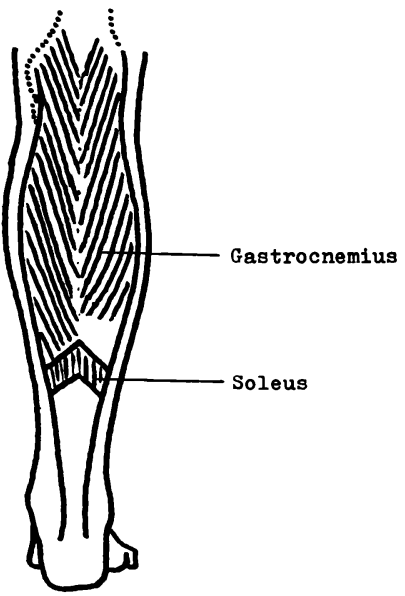

Vulpius's Technique

図 2

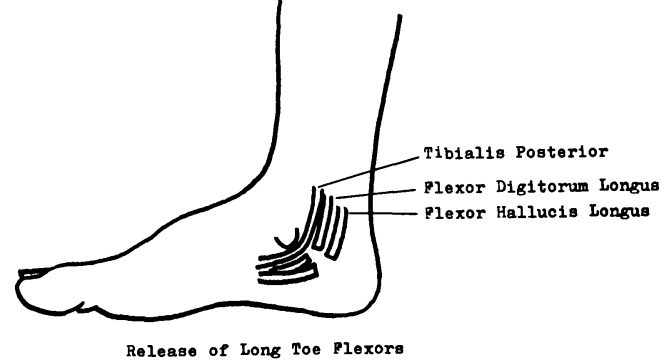

図 3

行させる目的で, Vulpius 法を行っている（図 2). なおこの方法で充分な効果が得られない場合は, ひら め筋々膜の切離も同時に行っており，いわゆるアキレ ス腱延長術まで要した症例はない。

槌趾変形は，ADL に多大の支障をきたし，たとえ ば畳上での転倒や疼痛ひいては痙縮の増強といった悪 循環を生じるので, 本変形に対する矯正術は重要であ る. 槌趾変形に対する手術としては, 従来足底趾節部 での long flexor の切腱術が行なわれて来たが，わ れわれは, 創部に直接体重がかかり, 術後早期の歩行 訓練が不可能であった点を考虑し，足関節内側部での long flexor の切腱術を行っている（図 3 ）. また術 前, 槌趾変形が軽度でも, 内反尖足矯正後槌趾が增強 してくる事及び桘趾変形が内反尖足に働く deformig factor である事を考えれば，同時に必ず切腱術を行 うべきである.

術後は, Vulpius 法及び long flexor の切腱術を 行った症例は, 翌日よりギプスなしで歩行訓練を行っ ている。

結果

手術効果は，ほぼ永久的で変形の再発はなく，また 手術による新たな変形はごく少数例を除き見られな かった，術後多くは，短下肢硬性装具がより簡単な plastic 装具，あるいは装具なしで歩行可となり，ま た杖歩行が杖なし歩行可となるなど歩行能力の改善が 見られた。 また clonus の軽減あるいは消失や抬抗筋 の筋力増大などの効果も認められた.

考察

片麻疸のような中枢神経麻疸は，中枢の各レベルで の種々な反射の影響により, 姿勢, 運動の異常を来た すむので，末梢神経麻㾝とは本質的に異なる．よって 
片麻㾝における変形は, 単なる筋力の imbalance に よる固定性変形ではなく, 病的姿勢反射, 異常な共同 運動, 伸張反射の元進などにより, 歩行などの動作時 に出現する dynamicなあのである.よって痤縮の程 度も, 姿勢や精神的緊張により強く影響を受け，しば しば臨床では, 足 clonus や腱反射方進が見られない にもかかわらず, 起立, 歩行では強い内反尖足が見ら れる例あ少なくない. したがって, 術前の評価におい ては, 筋緊張の強さも通常の筋力テストでは評価でき ず，単にベッド上での診察は不適当であり，起立・歩 行などの各種姿勢における筋緊張の程度, 不良肢位の 変化, 異常運動の有無等の観察が必要である. また日 時による変動も少なくないので数回にわたる観察を必 要とする.

なお，本矯正術は，末梢神経障害後の変形に対する 場合と質的に異なり，単なる延長による矯正効果とい うより, 痤直性の緩解及び拮抗筋の筋力増加という点 を重視している.すなわち, 柳沢・森本らによると, 中枢神経障害においては, 伸張反射の元進は伸筋・届 筋の双方にみられるが, 抗重力筋であり, かつ筋緊張 が大きな割合を占める伸筋により目立つ. この伸張反 射亢進は, gamma 系の機能元進による Ia 発射の 増加によるあのであり, この Ia 発射の増加は, 拮抗

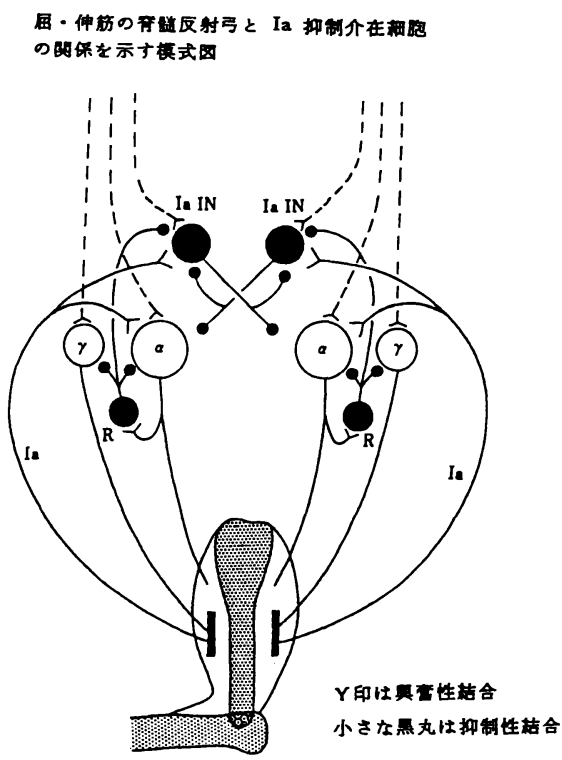

(柳沢倍夫。神理内科，7，1977より引用）
筋に対し，いわゆる Ia 抑制を強力に生じる. したが って，座縮の著しい伸筋から屈筋に対する抑制が，そ の逆の場合より著しく，よって腓腹筋切離は，拮抗筋 である前脛骨筋等への抑制の減少を生じ，その結果， 拮抗筋群の筋力増大に結びつくあのである (図 4).

以上より, 術後足関節背届力の増大が期待出来た ら，前脛骨筋腱移行術を併用する症例は従来考えられ ていたより少ないるのと思われる．なお本法にて矯正 出来ない intrinsic muscle の関与が大きいと思われ る症例が数例あり, 今後の課題と思っている.

\section{結語}

1. われわれは, 約 100 例の片麻㾝による足部変形 に対し手術療法を行い良好な結果を得ているので報告 した.

2. 片麻㾝による足部変形の大部分は, 筋・腱なよ゙ の小手術により充分な効果が得られた.

3. 高秢者が多く, 内科的にあ種々の合併症を伴う ため，なるべく侵襲の少ない麻酔・手術を行う.

4. 手術方針の決定に際しては, 起立歩行における 詳細な評価が必要である.

5. 槌趾変形は，たとえ術前軽度であっても，原則 として切腱術を同時に行う.

6. 術後, 長期間の安静・固定はなるべく避ける. われわれは, Vulpius 法及び long flexor の切腱術 を行った症例は，翌日よりギプスなしで歩行訓練を行 っている.

7. 術後, 有利な flexion synergy が誘発された 例も多く，その手術療法の意義は大きい.

\section{文献}

1）小泉正明ほか：片麻瘏内反尖足に対する再建手 術およびその予後調査. 整形外科, $28: 231$, 1977.

2）三島博信：脳卒中片麻瘦における整形外科的手 術. 総合リ八, 1: 143, 1973.

3）三島博信：下肢座性麻疸に対する手術療法。臨 整外, $11: 206,1976$.

4) Mooney, V., et al.: Surgical Approaches to Lower-Extremity Disability Secondary to Strokes. Clin. Orthop., 63: 142, 1969.

5)森本敬三ほか：脳血管障害後片麻疸の足部変形 に対する矯正術前後の動作筋電図学的検討. 整形 外科と災害外科, $27: 523,1978$.

6) Roper, B. A. et al.: Surgical Treatment of Equinovarus Deformity in Stroke $\mathrm{Pa}$ - 
tients. J. Bone and Joint Surg., 54-B: 178, 1972.

7) Roper, B. A. et al.: The Surgical Treatment of Equinovarus Deformity in Adults with Spasticity. J. Bone and Joint Surg., 60-B : 533, 1978.

8) Strayer, L. M. Jr.: An Operation to Relieve Spastic Contracture of the Calf Muscles. J. Bone and Joint Surg., 32-A : 671, 1950.

9）鈴木良平ほか：成人麻瘦足に対する手術成績1. 整形外科, $12: 459,1961$.

10）鈴木良平ほか：成人麻瘦足に対する手術成績 2 , 整形外科, $12: 535,1961$.

11）田川宏：片麻㾝の下服の手術. 総合リ八, 1 : 157, 1973.

12）田川宏ほか：片麻瘴における足部再建術の成 樍. リハビリテーション医学, 12: 148, 1975.

13) Tracy, H. W.: Operative Treatment of the Plantar-Flexed Inverted Foot in Adult Hemiplegia. J. Bone and Joint Surg., 58-A : $1142,1976$.

14) Vulpius, O.: Campbell's Operative Orthopedics, 4th Ed., 1884, Mosby Co., 1964.

15）柳沢信夫：パラプレジアの生理学的研究. 神経 内科, 7:398, 1977 .

翼 問 九大 野村 茂治

(1) 腱移行に際し，ギプス装着期間短縮等に対し， 特に工夫しているか.

(2) 足変形の名称はいかにして決定しているか.

(3) 腱延長に際し tightness と shortning を分
けているのか.

澌 問 長崎大 鈴木 良平 前脛骨筋移行のさいの手技についてうかがいたい.

\section{犋 問福岡県立粕屋新光園 松尾隆 （質問）}

(1) 槌趾に対して, 長母趾屈筋, 長趾届筋の切離を なさっているが, 術後母趾の不快な toeing-in 変形 は見られなかったのでしょうか.

\section{(発言)}

※この不快な toeing-in 変形を防止するために は長母趾屈筋の切腱はひかえ, ややひかえ目な処理を なさった方がいいと思う．私は先天性内反足などでは むしろ内反変形を防止する筋として温存の方向をとっ ています。

\section{回 答}

浅山 滉

アキレス腱延長（Vulpius）の程度をどう決めてい るかという御質問に対して

あくまであ dynamic phase において, 何回も check したのちに, Vulpius の程度をきめている.

at restでも明らかな contracture を有している 場合であれば延長の程度を強くするといったように， その程度は経験によっている．但し，アキレス腱の多 少の拘縮は stance phase における knee stability に大切な要素となるので, 放置すべきである. 